\title{
SPIRIT KEILMUAN WAHYU MEMANDU ILMU DALAM PENGEMBANGAN HUKUM ISLAM
}

\author{
Deden Najmudin \\ Fakultas Syariah Dan Hukum UIN Sunan Gunung Djati Bandung \\ Email: deden.najmudin@uinsgd.ac.id
}

\begin{abstract}
In the development of Islamic law that covers all aspects of people's lives, both in the hereafter problem with all its problems, as well as world problems with all these problems require a new paradigm of scientific mindset. The more advanced development of science and technology also influences the progress of social life, culture, politics, economics and others. So the authors take up this theme using descriptive and comparative methods, and the type of data used in this study is qualitative data. Islamic law requires a new paradigm of mindset and renewal of the views of a problem, especially in everyday life or we can call it contemporary fiqh. The paradigm of the new paradigm becomes more severe, due to contemporary problems, even more complicated when seen from the perspective of fiqh. However, the tradition of the fuqaha used to guide the dynamics of life in his day, so that in this day and age we can imitate the ulama fuqaha by at least contributing to the development of science and understanding, with various kinds of problems in society in accordance with the times, so that the problems of religious life the people are always guided. This paper will raise the opportunity given by Islamic law itself to its people to always criticize it, which allows the emergence of new paradigms along with the emergence of new problems in society.
\end{abstract}

Keywords: Paradigm; Islamic Law and Science

\begin{abstract}
Abstrak
Dalam pengembangan hukum Islam yang terdiri dari aspek dalam kehidupan umat, baik permasalahan akhirat dengan segala persoalannya, ataupun permasalahan dunia dengan segala persoalannya tersebut membutuhkan paradigma pola fikir baru keilmuan. Semakin majunya perkembangan ilmu pengetahuan dan teknologi memberikan pengaruh juga terhadap kemajuan berkehidupan sosial, ekonomi, budaya, politik, dan lain-lain. Maka penulis mengangkat tema ini menggunakan metode deskriptif dan komparatif, dan Jenis data yang digunakan dalam penelitian ini adalah jenis data kualitatif. Hukum Islam membutuhkan paradigma pola fikir baru dan pembaharuan terhadap pandanganpandangan suatu permasalahan, terutama di dalam kehidupan sehari-
\end{abstract}


hari atau bisa kita namakan sebagai fiqih kontemporer. Paradigma pola pikir baru tersebut menjadi lebih berat, dikarenakan permasalahan yang kontemporer, bahkan juga sulit dimengerti dalam perspektif fiqihnya. Namun tradisi para fuqaha dulu dalam memandu dinamika kehidupan di zamannya, sehingga di zaman sekarang ini kita bisa mencontoh Ulama fuqaha dengan sedikitnya memberikan kontribusi terhadap pengembangan ilmu dan pemahaman, dengan berbagai macam problematika di masyarakat sesuai dengan perkembangan zaman, sehingga problematika kehidupan antar beragama dapat terbimbing. Penulis mencoba untuk mengangkat sebuah pembahasan yakni peluang hukum Islam terhadap umatnya agar bisa mengkritisinya, yang mungkin bisa munculnya pandangan baru seiring muncul masalah terbaru di masyarakat.

Kata kunci: Paradigma; Hukum Islam; Keilmuan

\section{Pendahuluan}

"Taatlah kepada Allah dan Rasul-Nya". (QS. An-nisa: 59). Perintah Allah swt. dalam Al-Qur'an yang memperkenalkan tentang pembaharuan terhadap struktur masyarakat Arab pada saat itu. Sebuah otoritas politik baru dengan kekuasaan legislatif yang telah ditegakkan. Perubahan yang terjadi di masyarakat Arab pada saat itu diantaranya proses pembuatan peraturan hukum secara teknis. Dalam proses-proses tersebut, ukuran perilaku-perilaku ditempatkan di dalam hak dan kewajiban. Dibentuk juga penanggulangan terhadap pelanggaran hak maupun kewajiban. Proses tersebut berlangsung karena ada syarat ukuran yang diterima.

Salah satu permasalahan khusus pada waktu itu missalnya tentang keislaman, diantaranya adalah soal meminum khamar dan juga tentang riba. Hal tersebut, diharamkan oleh Allah melalui Firman-Nya. Tetapi AlQur'an tidak memberikan penjelasan mengenai prakteknya dalam peristiwa hukum. Di dalam perkembangannya kemudian, meminum khamar juga ternyata merupakan suatu perbuatan yang bisa dihukum cambuk. Adapun permasalahan riba termasuk ke dalam pembahasan hukum perdata, yakni karena merupakan transaksi yang batal. Pada prinsipnya, Allah satu-satunya pembuat hukum oleh karena itu perintahnya harus menjadi hal yang utama dalam setiap aspek kehidupan yang secara lengkap diatur di dalam Firman-Nya. Kemudian pada peristiwa selanjutnya memperlihatkan bahwa Al Qur'an memiliki sebuah 
konsep yang diibaratkan muqaddimah dari sebuah kitab dalam hukum Islam, selanjutnya diamalkan secara kontinyu. ${ }^{1}$

Hukum Islam merupakan suatu aturan yang sebenarnya sudah ditentukan oleh Allah melalui Al Qur'an, yang selanjutnya menjadi dasar ilmu fiqih atau suatu pengembangan terhadap hukum Allah. Terdapat empat dasar dalam perwujudan ajaran Allah tersebut, yang berbeda tetapi berkaitan satu sama lain, yang kita kenal dengan akar yurisprudensi. Karena empat dasar tersebut adalah Al Qur'an, As Sunnah, qiyas (berpikir analogis), dan Ijma para Ulama mujtahid. ${ }^{2}$

Modernisme di dalam hukum Islam lebih mudah kita fahami dengan kebebasan dalam menafsirkan ajaran agama Islam, ijtihad ilmiah dalam pemikiran lainnya. Karena pemikiran ini berusaha untuk tidak membatasi akal dan membekukan kehidupan masyarakat. ${ }^{3}$

Pembaharuan hukum Islam di masa sekarang ini hingga yang akan dating, mesti mencakup aspek teologis dalam melandasi pemikiranpemikiran para pakar hukum, terutama tentang apa sumber hukum dan bagaimana pengetahuannya di dalam hukum Islam. Baik dengan menggunakan akal disamping wahyu bisa mengetahui perbuatannya itu baik atau buruknya, sebelum atau sesudahnya turun wahyu yang mewajibkan syara' atau tidaknya. Disamping itu, dalam epistemologi hukum Islam juga sudah waktunya dikembangkan oleh para ahli dalam mengembangkan hukum Islam dengan memposisikan hukum sebagai suatu hasil ilmu. ${ }^{4}$

Menurut teori, dari awal datangnya syari'at Islam hanya memiliki tujuan untuk kemaslahatan manusia, dengan kata lain bahwa syariat Islam diciptakan demi untuk kebahagiaan umat manusia secara lahir maupun batin, yakni untuk kemashlahatan dunia dan akhirat. ${ }^{5}$ Adapun di dalam aspek kultural, sosial, maupun historis dengan adanya teks yg kurang tidak mendapatkan perhatian yang memadai. Karena teks hanya

\footnotetext{
${ }^{1}$ Djafar Alkatiri, Jurnal Ilmiah Al-Syir'ah, Hukum Islam Perspektif Paradigma Baru Keilmuan, 2003, Hlm.2

2 Ibid

3 Wildani Hefni, Jurnal Hukum Islam, Fragmen Kajian Hukum Islam di Perguruan Tinggi Keagamaan Islam Indonesia, Volume 16 Nomor 1, Juni 2018, Hlm. 8

${ }^{4}$ Djafar Alkatiri, Loc. cit

${ }^{5}$ Djafar Alkatiri, Op. cit. hlm.3
} 
mencakup sendiri, sedangkan pemaknaan suatu teks tanpa melibatkan pemahaman-pemahaman konteks dari luar teks. ${ }^{6}$

\section{Metodologi}

Metode yang digunakan dalam penelitian ini adalah deskriptif komparatif, yakni penelitian dengan mengutamakan pengamatan terhadap suatu peristiwa di masa lalu dan membandingkannya dengan perkembangan keadaan di zaman sekarang. ${ }^{7}$ Adapun data yang dipakai didalam penelitian ini merupakan jenis data kualitatif, yang datanya diperoleh dari sumber data tertulis dan juga berupa pendapat Imam madzhab, ulama, serta ahli hukum Islam yang tertuang di beberapa literatur yang ditemukan oleh penulis. ${ }^{8}$

\section{Spirit Keilmuan Wahyu Memandu Ilmu dalam Pengembangan Hukum Islam}

Jika kita lihat dari aspek tata bahasa, hukum memiliki makna "menetapkan sesuatu pada yang lain". Seperti hukum khamar yaitu haram, dan juga air susu hukumnya yaitu halal. Adapun menurut para Ulama ushul, sebagaimana menurut pendapat Abu zhahrah yaitu "titah (khithab) syari' yang berkaitan dengan perbuatan mukallaf, baik berupa tuntutan, pilihan atau wadh'i". Hukum Islam merupakan aturan-aturan yang dibuat dan telah ditetapkan pokoknya untuk mengatur hubunganhubungan antara manusia dengan Tuhannya, hubungan manusia dengan manusia lainnya, dan manusia dengan alam semestanya. ${ }^{9}$

Di dalam AI Qur'an ataupun di dalam literatur hukum lainnya tidak ditemukan kata hukum islam itu sendiri. Yang ada di dalam Al Qur'an terdapat kata syari'ah ${ }^{10}$, fiqih, hukum Allah dan seakar dengannya.

\footnotetext{
${ }^{6}$ Muhammad Solikhudin, AHKAM, Pengembangan Hukum Islam Kontemporer: Dari Qawlī Ke Manhajī, Volume 7, Nomor 1, Juli 2019, Hlm. 175 hlm. 38

7 Tajul Arifin, Teknik Penulisan Skripsi, (Bandung : Gunung Djati Press, 2011)

${ }^{8}$ Cik Hasan Bisri, Penuntun Penyusunan Rencana Peelitian dan Penulisan Skripsi Bidang Ilmu Agama. Jakarta : Raja Grafindo Persada, 2003) hlm. 63

${ }^{9}$ Djafar Alkatiri, Op. cit. hlm.3

${ }^{10}$ Amrullah Ahmad SF, Dimensi Hukum Islam dalam Hukum Nasional, Jakarta : Gema Insani Press, 1996, hlm. 87
} 
Adapun Hukum Islam adalah sebuah terjemah dari "Islamic Law" yng merupakan literatur dari Barat. ${ }^{11}$

Hasbi As-Siddiqiy berpendapat bahwa hukum Islam merupakan segala daya upaya yang dilakukan oleh seorang muslim dengan melibatkan syariat Islam yang ada. Dalam hal ini Hasbi menjelaskan juga bahwasannya hukum Islam akan tetap hidup sesuai dengan peraturan yang ada. ${ }^{12}$ Dalam pengertian hukum Islam ini lebih mendekati kepada makna dari fiqh itu sendiri.

Kejelasan mengenai arti hukum Islam perlu difahami terlebih dahulu apa itu hukum. tetapi, untuk memahami dengan mudah walaupun masih banyak kekurangan, pengertian yang dikutip Muhammad Muslehuddin dari Oxford English Dictionary bahwa, menurutnya, hukum merupakan sekumpulan aturan-aturan, yang berupa aturan formal ataupun bersumber dari adat suatu masyarakat atau suatu bangsa yang mengikat bagi anggotanya. ${ }^{13}$

Jikalau hukum dikaitkan dengan Islam, maka hukum Islam adalah Seperangkat peraturan berdasarkan wahyu Allah dan Sunnah Rasul mengenai tingkah laku orang mukallaf yang diakui dan diyakini berlaku dan mengikat untuk semua umat yang beragama Islam. ${ }^{14}$ Dari definisi tersebut kita bisa memahami hukum Islam yang meliputi Hukum Syariah dan Hukum Fiqh, karena arti syara' dan fiqh terkandung didalamnya.

Secara epismologis kata syariah berarti "jalan tempat keluarnya air minum", yang kemudian diumpamakan sebagai jalan lurus yang harus ditempuh. ${ }^{15}$ Maka bisa kita simpulkan syariah itu identik dengan agama, dan juga sesuai dengan firman Allah dalam Al Qur'an surat al Maidah ayat 48 , as Syura ayat 13 , dan al Jasiyah ayat 18 . Seiring dengan perkembangan kata syariah dipakai dalam Islam, baik yang ditetapkan langsung oleh al-

11 Dalam penjelasan tentang hukum Islam dari literatur Barat ditemukan definisi "Keseluruhan khitab Allah yang mengatur kehidupan setiap muslim dalam segala aspeknya". Dari definisi ini arti hukum Islam lebih dekat dengan pengertian syariah

Lihat Joseph Schacht, An Introduction to Islamic Law, Oxford University Press, 1964, hlm. 1

${ }^{12}$ Amir Syarifuddin, Ushul Fiqh, Jakarta: Kencana, 2009, hlm. 14

13 https://duniatanah.wordpress.com

14 Ibid

15 Muhammad Abu Zahrah, Ushul al-fiqh, hlm. 5 dan dibandingkan Abdul Wahab Khallaf, Ilmu Ushul al-fiqh, hlm. 111 
Quran dan Sunnah, maupun yang telah dicampuri oleh pemikiran manusia (Ijtihad). ${ }^{16}$

Kata fiqh memiliki makna "mengetahui sesuatu dan memahaminya dengan baik". Menurut pendapat Abu Zhahrah didalam kitab Ushul Fiqhnya adalah "mengetahui hukum-hukum syara yang bersifat amaliah yang dikaji dari dalil-dalilnya secara terperinci". Dari pengertian diatas bisa kita simpulkan, fiqh itu bukanlah hukum syara itu sendiri, akan tetapi merupakan interpretasi terhadap hukum syara. Karena fiqh hanya merupakan interpretasi yang bersifat zhanni yang terikat dengan suatu keadaan yang melingkupinya, oleh karena itu fiqh senantiasa berubah mengikuti perubahan waktu dan tempat. ${ }^{17}$

Teori penerimaan otoritas hukum diperkenalkan oleh seorang orientalis Kristen, H.A.R. Gibb dalam bukunya, The Modern Ternds of Islam, seperti dikutip $\mathrm{H}$. Ichtijanto bahwa orang Islam jika menerima Islam sebagai agamanya, ia akan menerima otoritas hukum Islam kepada dirinya. Berdasarkan teori ini, secara sosiologis, orang yang memeluk Islam akan menerima otoritas hukum Islam dan taat dalam menjalankan syariat Islam. Namun ketaatan ini akan berbeda satu dengan lainnya, dan sangat bergantung pada tingkat ketakwaan masing-masing. ${ }^{18}$

Selain Gibb, Charles J. Adams, juga mengungkapkan bahwa hukum Islam merupakan subjek terpenting dalam kajian Islam karena sifatnya yang menyeluruh; meliputi semua bidang hidup dan kehidupan Muslim. Berbeda degan cara mempelajari hukum-hukum lain, studi tentang hukum Islam memerlukan pendekatan khusus, sebab yang termasuk bidang hukum Islam itu bukan hanya apa yang disebut dengan istilah law dalam hukum Eropa, tetapi juga termasuk masalah sosial lain di luar wilayah yang dikatakan Law itu. ${ }^{19}$

\section{Hukum Islam Sebagai Ilmu}

Pengertian hukum islam menurut para pakar dapat ditinjau dalam 2 sisi, yang pertama yaitu hukum sebagai ilmu dan hukum sebagai hasil

\footnotetext{
16 https://duniatanah.wordpress.com

17 Djafar Alkatiri, hlm. 4

${ }^{18}$ H. Ichtijanto S.A, Pengembangan Teori Berlakunya Hukum Islam di Indonesia (Remaja Rosdakarya, Bandung, 1991), hlm. 95-149

${ }^{19}$ Charles J. Adams, dalam Muhammad Daud Ali, Hukum Islam, Pengantar Ilmu Hukum dan Tata Hukum Islam di Indonesia, Cet. VII (Jakarta: Radja Grafindo Persada, 1999), hlm. 11.
} 
ilmu. Adapun hukum sebagai hasil ilmu bisa kita sebut sebagai kumpulan hukum syara' hasil dari pada ijtihad. Selain itu, definisi menurut Abu Zahrah sebagai suatu ilmu yang mengupayakan lahirnya hukum syara amali yang diambil dari dalil-dalil. Pertama sebagai ilmu, Kedua hukumhukum syara' amali, dan Ketiga dalil-dalil. Hukum sebagai ilmu dibuktikan dengan karakteristik keilmuan sebagai berikut: dihasilkan dari akumulasi pengetahuan yang tersusun melalui asas-asas tertentu, Pengetahuan-pengetahuan itu terjaring dalam satu kesatuan sistem dan Mempunyai metode-metode tertentu. ${ }^{20}$

Hukum Islam merupakan seperangkat aturan berdasarkan wahyu Allah dan Sunnah Rasul tentang tingkah laku manusia mukalaf yang diakui dan diyakini berlaku dan mengikat untuk semua umat yang beragama Islam. ${ }^{21}$ Dalam perkembangannya hukum Islam dikenal dengan berbagai macam istilah. Secara umum Jasser auda membedakan hukum Islam dalam 3 (tiga) istilah, yaitu:22

Pertama, Syariah yaitu wahyu yang diterima oleh Nabi Muhammad saw. dan dipraktikkan dalam risalah dan misi kehidupan beliau. Dengan kata lain syariah adalah Al-Qur'an dan Sunnah. Kedua, Fikih yaitu koleksi, dalam jumlah besar, pendapat hukum yang diberikan oleh ahli hukum Islam dari berbagai mazhab, berkenaan dengan aplikasi Syariah pada berbagai situasi kehidupan nyata sepanjang 14 (empat belas) abad terakhir. Ketiga, Fatwa yaitu aplikasi syariah atau fikih (di atas) dalam kehidupan nyata umat Islam saat ini.

Penjabaran dan penerapan hukum Islam yang dijalankan oleh umat Islam didasari oleh dua hal yaitu Al-Qur'an dan Sunnah sebagai sumber hukum utama. ${ }^{23}$ Pengetahuan mengenai hukum mencakup tentang dalil, perintah, dan larangan, kemudian diakumulasikan melalui asas tertentu hingga tersusun dengan baik, dikarenakan satu dengan yang lainnya terikat secara fungsional dalam satu sistem. Pengetahuan itu tidak berdiri sendiri, akan tetapi saling berhubungan dengan perintah dan larangan,

20 Djafar Alkatiri, Ibid

21 Mardani, Hukum Islam "Kumpula Peraturan tentang Hukum islam di Indonesia, (Jakarta: PT Fajar Interpratama Mandiri, 2013), hlm. 10

22 Jasser Auda, Membumikan Hukum Islam, hlm. 24

23 Syahrul Sidiq, IN RIGHT Jurnal Agama dan Hak Azazi Manusia, Maqasid Syari'ah dan Tantangan Modernitas: Sebuah Telaah Pemikiran Jasser Auda, Vol. 7, No 1, November 2017, hlm. 142 
karena suatu pesan akan berwujud dalil ketika berhubungan antara makna dengan perintah atau larangan. ${ }^{24}$

Dapat kita pahami dalam kitab-kitab yang disusun oleh Ulamaulama fiqh, selain pembahasannya terkait masalah fiqhiyah, juga sebagai hasil ilmu, hyang tentunya memiliki suatu konsekuensi, oleh karena itu harus bersedia dikaji ulang, dan jangan kebal kritik. Yang artinya, hasil fiqh yang tertulis di dalam kitab fiqh itu bisa menjadi sumber informasi yang menunjukkan bahwa para Ulama telah membahas masalah fiqhiyah tersebut. Selain itu juga menunjukkan bahwa fiqh sebagai ilmu yang tak pernah berhenti melakukan tugas dan memiliki kemampuan untuk beradaptasi dengan waktu dan tempat sehingga memotivasi lahirnya peradaban manusia yang baru disertai dengan konsepnya yang prospektif. ${ }^{25}$ Di dalam fiqh tidak hanya ijtihad dalam menemukan suatu hukum, tapi ijtihad dalam prakteknya dalam kehidupan sehari-hari, karena fiqh dan hasil fiqh selalu bekaitan antara satu sama lainnnya dalam kehidupan manusia, yang juga merupakan kebijaksanaan dalam pemikiran. ${ }^{26}$

\section{Paradigma Baru Hukum Islam}

Kita dapat memahami hukum Islam dalam dua dimensi keilmuan. Pertama, hukum Islam dalam dimensi ilahiyah, karena dapat diyakini memiliki ajaran yang sumbernya langsung dari yang Maha suci, yang Maha sempurna, dan yang Maha benar. Pada dimensi hukum Islam ini umat Islam meyakini sebagai ajaran suci, yang sumbernya berasal dari yang Maha Suci, sehingga kesakralannya selalu terjaga. Dengan demikian, hukum Islam merupakan syariat yang cakupannya begitu luas, bukan hanya terbatas masalah fiqh dalam arti terminology, yakni meliputi juga dalam hal keyakinan, akhlak dan amaliah. Kedua, hukum Islam dalam dimensi insaniyah. Pada dimensi tersebut, upaya kesungguhan manusia terhadap pemahaman mengenai ajaran suci berdasarkan kepada dua perspektif, yakni perspektif kebahasaan dan maqasid. Pada pendekatan ini, pemahaman hukum Islam yang merupakan hasil daripada pemikiran

\footnotetext{
24 Djafar Alkatiri, hlm. 5

25 Ibid

26 Ibid
} 
yang berdasarkan pada pendekatan yang kita kenal sebagai ijtihad atau kita sering menyebutnya sebagai istinbath al-ahkam. ${ }^{27}$

Selanjutnya, seiring perkembangannya Hukum Islam melahirkan istilah-istilah baru, diantaranya fiqh, qadla dan fatwa. Fiqh merupakan produk utama hukum Islam secara individual, sedangkan Fatwa merupakan produk Ulama, baik secara individual ataupun kolektif karena merupakan jalan keluar terkait suatu persoalan ataupun jawaban dari pertanyaan-pertanyaan dari umat Islam pada waktu itu. Selanjutnya qadla merupakan hukum Islam berupa keputusan-keputusan dari suatu permasalahan yakni hasil ijtihad individual atau kolektif para Ulama. ${ }^{28}$

Harun Nasution berpendapat bahwa paradigma baru merupakan sebuah kerangka berpikir, atau pemahaman, adat istiadat, institusiinstitusi lama, yang diakibatkan oleh perkembangan ilmu pengetahuan dan teknologi modern. ${ }^{29}$

Di dunia Islam, Pembaharuan pola pikir secara serempak muncul pada Abad ke 19 dan awal abad ke 20, yang merupakan suatu akibat langsung dari adanya hubungan antara Islam dengan peradaban Barat. Hubungan antara india dan inggris, Mesir dan Perancis serta Turki dengan negara-negara yang ada di Eropa Barat, menjadikan para ilmuan sadar dengan ketertinggalannya, karena tertinggal dari penguasaan ilmu pengetahuan dan teknologi. Kemudian dalam mengejar ketertinggalannya itu, mereka diberikan motivasi dan dorongan untuk mengembangkan potensi mereka. Setelah itu, umat Islam perlu dibekali pemikiran teologi yang mendorong untuk maju, serta pemikiran fiqh sebagai ketentuan hukum yang tidak akan menjadi kendala kemajuan, tapi sebaliknya dapat memberi kepastian hukum sesuai dengan kemajuan tersebut. ${ }^{30}$

Fiqh Islam menurut paradigma baru merupakan pola fikir dalam sebuah ijtihad untuk merubah faham, adat istiadat, atau pemikiran lama yang disesuaikan dengan suasana baru yang ditimbulkan dari perkembangan ilmu pengetahuan dan teknologi yang disertai dengan tantangan dalam mengupayakan Islamisasi ilmu pengetahuan. ${ }^{31}$

27 Jaih Mubarok, Sejarah dan Perkembangan Hukum Islam, Remaja Rosdakarya, Cet I, Bandung, 2000.

${ }^{28}$ Djafar Alkatiri, Ibid.

${ }^{29}$ Harun Nasution, Pembaharuan dalam Islam, Bulan Bintang, Jakarta, 1975, hlm.11

30 Djafar Alkatiri, hlm. 6

31 Ibid 
Fiqih yang merupakan hasil pemikiran manusia tidak bersifat kaku menghadapi perkembangan dan perubahan zaman, dikarenakan fiqh diharuskan bisa memberi jawaban-jawaban atas permasalahan dalam hidup dan kehidupan manusia. Disamping itu selain perubahanperubahan dalam kehidupan senantiasa terbuka dan mesti diikuti. Melihat implikasi sosial dengan diterapkannya produk pemikiran hukum tersebut, selain terus terjaga dari kesesuaiannya terhadap Al-Qur'an dengan perilaku manusia. ${ }^{32}$

Dalam persoalan-persoalan muamalah tuntutan untuk berijtihad ini sangatlah besar, teruama yang berkaitan dengan masalah ekonomi dan keuangan ataupun temuan-temuan ilmiah yang berkaitan persoalan dalam kehidupan manusia lainnya baik itu yang berkaitan dengan jasa perbankan dengan berbagai produknya, diantaranya simpan pinjam, penukaran uang, dan juga produk-produk lain yang jika ditinjau dari aspek hukum menjadikannya haram ataupun halal memerlukan kajian ijtihad. 33

Demikian juga dalam penemuan-penemuan ilmiah lainnya dalam transplantasi organ di dalam tubuh manusia, ada saja kemungkinan pengambilannya dari orang hidup ataupun yang sudah mati, atau mungkin saja diambil dari binatang. Oleh karena itu dibutuhkan ijtihad di dalam mencari hukum mengenai kebolehan tindakan medis tersebut, atau suatu tindakan medis yang sesuai dengan syara', perlu dilakukan ijtihad sebagai reaksi terhadap perubahan dan perkembangan kehidupan manusia, maka ijtihadnya pun kontemporer. ${ }^{34}$ Selanjutnya, jika kita lihat perubahan dan perkembangan dari hasil pemikiran-pemikiran fiqih terdahulu, terlihat perbedaan diantara keharusan hukum dan tuntutan sosial, ataupun ketika belum menyentuh permasalahan tersebut. Oleh sebab itu, fiqh kontemporer memerlukan ijtihad dari para Ulama yang mampu melakukannya secara kualitatif. ${ }^{35}$

Padahal syariat Islam di turunkan Allah kepada umat manusia untuk diaplikasikan dalam kehidupan. Kekuatan syariat Islam dalam menata ketertiban dan kedamaian masyarakat selain yang bersifat normatif dalam bidang ubudiah dan muamalah, juga harus ditopang

\footnotetext{
32 Ibid

${ }^{33}$ Djafar Alkatiri, hlm. 7

34 Ibid

35 Dede Rosyada, Hukum Islam dan Pranata Sosial, LSIK, Jakarta, 1993, hlm.173-
} 175. 
dalam bidang jinayah agar segala hak-hak masyarakat yang terampas bisa dikembalikan. Oleh karena itu, hukum pidana Islam sebagai hukum publik harus dilegislasi menjadi hukum positif. ${ }^{36}$

\section{Ubudiah dan Muamalah}

Secara individual memang dalam pelaksanaan syariat Islam hanya pada tataran normatif berhubungan dengan ubudiah dan muamalah, sedangkan yang berhubungan dengan hukum publik di dalam penegakan hukum Islam, harus ada campur tangan negara dalam pertimbangan semua aspek sosiologis untuk mendukung proses implementasinya. ${ }^{37}$

Penegakan syariat Islam dalam menghadapi tantangan modernisasi bisa kita ketahui dengan melihat prinsip-prinsip syariat Islam mengenai tatanan hidup baik secara horizontal maupun vertical. Telah ditetapkan oleh para fuqoha mengenai kaidah bahwa hukum asal segala sesuatu dalam bidang material dan hubungan antara sesama manusia adalah boleh, kecuali sesuatu itu bisa jadi terlarang jika ada dalil yang mengaturnya. ${ }^{38} \mathrm{Hal}$ tersebut tidak sejalan dengan kaidah hukum dalam bidang ibadah, karena telah ditentukan Batasan-batasannya, dan juga dapat terjaga kesimpangsiurannya jika terdapat nash yang tidak dapat ditafsirkan. Dan juga terdapat satu kaidah yang menyebutkan "ibadah tidak bisa dilakukan kecuali apabila ada dalil yang menunjukkan bahwa sesuatu itu telah diperintahkan oleh Allah dan telah dicontohkan oleh Rasulullah Saw". Berdasarkan prinsip tersebut bisa kita pahami terkait perkembangan dan pembaharuan yang meliputi semua bentuk mu'amalah, diperbolehkan dalam syariat Islam, selama sejalan dengan prinsip syariat Islam. Perlu kita sadari bahwa kehidupan manusia selalu mengalami perkembangan dan perubahan baik pada aspek muamalah, yang di dalamnya diatur dan ditetapkan secara umum mengenai dasardasar hukum. ${ }^{39}$

\section{Qat'i Dalalah dan Zhanniy Dalalah}

Sebenarnya inti daripada ajaran Islam bisa kita klasifikasikan jadi dua. Pertama, ajaran yg bersifat universal, permanen dan absolut,

${ }^{36}$ Hasyim Nawawi, Episteme, Hukum islam dalam Perspektif Sosial-budaya Di Era Reformasi, Vol. 8, No 1, Juni 2013, hlm. 11

37 Ibid

38 Djafar Alkatiri, hlm. 8

${ }^{39}$ Faturahman Djamil, Filsafat Hukum Islam, Bag. I, Logos wacana Ilmu, Jakarta, 1997, hlm. 40-43. 
termasuk didalamnya ajaran Al Quran dan Al Hadist mutawatir yang penjelasannya sudah jelas. ${ }^{40} \mathrm{Kedua}$, adalah kebalikannya yakni ajaran yang bersifat tidak universal, tidak permanen, dan relatif yang bisa diubah dan berubah. Kedua hal tersebut merupakan ajaran Islam yang dihasilkan dari proses ijtihad. Para fuqoha mengenal kerangka berpikir tersebut sebagai dikotomi antara dalil qat'i dan dalil zhanniy, dalam keberadaan dan penunjukannya. ${ }^{41}$

\section{Integritas Akal dengan Wahyu}

Sumber hukum Islam yang paling utama adalah bersumber dari Allah, dikarenakan semua orang termasuk Rasulullah pun taat pada hukum Allah. Disini kita bisa kita lihat bawha Rasulullah diberi tugas untuk menyampaikan dan melaksanakan perintah-perintah Allah kepada umat manusia, karenanya semua ketentuan Allah, hyang berupa Al Quran dan As Sunnah di jelaskan dan dilaksanakan oleh Rasulullah. ${ }^{42}$

Mengutip dari pernyataan Rasyid Ridho, Yusuf Qardhawi mengungkapkan bahwa "untuk mencetak seorang mujtahid saat ini bukan menjadi sesuatu yang sulit, karena disamping banyak orang yang jenius juga fasilitas pembinaan mereka jauh lebih lengkap dibandingkan pada masa awal Islam dulu, sudah banyak sekolah yang dibentuk dengan sistem pendidikan yang relatif cukup baik, dan yang paling penting adalah tentang hasil kajian sosiologis sudah cukup banyak yang dituangkan dalam bentuk buku-buku ilmu sosial, yang semuanya itu merupakan bidang keilmuan yang harus dipelajari oleh seorang Ulama, dan juga mudah untuk mereka pelajari". Maka dari itu, dalam mencetak mujtahid di zaman sekarang ini tidaklah mustahil, karena dapat ditempuh melalui proses akademis oleh siapapun yang memiliki keinginan dan kemampuan, baik dari segi ilmu kefiqihannya ataupun intelektualitasnya. 43

\section{Penutup}

Dapat kita simpulkan mengenai sumber dari syariat Islam yang berupa hukum amaliah antara sesama manusia, agar mampu menjadi rujukan di dalam menetapkan hukum Islam. Kemudian di dalam fiqh

\footnotetext{
${ }^{40}$ Djafar Alkatiri, hlm. 9

41 Ibid. hlm. 43.

42 Masbukin \& Alimuddin Hassan, Jurnal TOLERANSI, Akal dan Wahyu, antara perdebatan dan pembelaan dalam sejarah, Vol. 8, No. 2, Juli-Desember 2016, hlm. 63

${ }^{43}$ Djafar Alkatiri, hlm. 10
} 
Islam kontemporer yang merupakan sebuah pemikiran-pemikiran ijtihad untuk merubah pemahaman, adat istiadat, dan pemikiran terdahulu yang sesuai dengan perkembangan dan perubahan zaman yang disebabkan oleh kemajuan ilmu pengetahuan dan teknologi disertai dengan tantangan-tantangan dalam proses Islamisasi ilmu pengetahuan tersebut. Sehingga hukum bukan dibuat oleh masyarakat seperti sistem hukum di Barat. Dengan campur tangan wahyu Tuhan, manusia dapat menemukan batasan perilaku kehidupan yang benar. Dan fiqh merupakan sumber hukum Islam yang berasal dari pemikiran para Ulama baik individu maupun kelompok dari suatu permasalahan dalam kehidupan umat muslim pada waktu itu. Sedangkan qadla merupakan hukum Islam berupa keputusan-keputusan dari suatu permasalahan yakni hasil ijtihad individual atau kolektif para Ulama. Dikarenakan Fiqh tidak selalu ijtihad dalam mencari suatu hukum, akan tetapi ijtihad didalam melaksanakannya, karena fiqh merupakan ilmu-ilmu yang berkaitan dengan pengamalan-pengamalan di dalam kehidupan manusia.

\section{Daftar Pustaka}

Abu Zahrah, Imam Muhammad. Ushul al-Fiqh. Beirut : Dar al-Fikr. T.th.

Alkatiri, Djafar. Jurnal Ilmiah Al-Syir'ah, Hukum Islam Perspektif Paradigma Baru Keilmuan, 2003.

Amrullah, Ahmad SF. Dimensi Hukum Islam dalam Hukum Nasional. Jakarta: Gema Insani Press, 1996.

Arifin, Tajul. Teknik Penulisan Skripsi. Bandung: Gunung Djati Press, 2011.

Bisri, Cik Hasan. Penuntun Penyusunan Rencana Peelitian dan Penulisan Skripsi Bidang Ilmu Agama. Jakarta: Raja Grafindo Persada, 2003.

Charles J. Adams, dalam Muhammad Daud Ali, Hukum Islam, Pengantar Ilmu Hukum dan Tata Hukum Islam di Indonesia, Cet. VII Jakarta: Radja Grafindo Persada, 1999.

Djamil, Faturahman. Filsafat Hukum Islam. Bag. I. Jakarta: Logos wacana Ilmu, 1997.

H. Ichtijanto S.A, Pengembangan Teori Berlakunya Hukum Islam di Indonesia, Bandung: Remaja Rosdakarya, 1991. 
https://duniatanah.wordpress.com

Khallaf, Abdul Wahab. Ilmu Ushul Fiqih. Jakarta: Pustaka, 2003.

Mardani, Hukum Islam, Kumpulan Peraturan tentang Hukum islam di Indonesia, Jakarta: PT Fajar Interpratama Mandiri, 2013.

Masbukin \& Alimuddin Hassan, "Akal dan Wahyu, Antara Perdebatan Dan Pembelaan Dalam Sejarah", Jurnal TOLERANSI. Vol. 8, No. 2, (Juli-Desember 2016).

Mubarok, Jaih. Sejarah dan Perkembangan Hukum Islam. Cet I. Bandung: Remaja Rosdakarya, 2000.

Muhammad Solikhudin. "Pengembangan Hukum Islam Kontemporer: Dari Qawlī Ke Manhajī”. AHKAM. Volume 7. Nomor 1. (Juli 2019).

Nasution, Harun. Pembaharuan dalam Islam. Jakarta: Bulan Bintang, 1975.

Rosyada, Dede. Hukum Islam dan Pranata Sosial. LSIK. Jakarta: Rajawali Pers, 1993.

Schacht, Joseph. An Introduction to Islamic Law. Oxford: Oxford University Press, 1964.

Syahrul Sidiq, "Maqasid Syari'ah dan Tantangan Modernitas: Sebuah Telaah Pemikiran Jasser Auda". IN RIGHT Jurnal Agama dan Hak Azazi Manusia, Vol. 7, No 1, (November, 2017).

Syarifuddin, Amir. Ushul Fiqh. Jakarta: Kencana, 2009.

Wildani Hefni. "Fragmen Kajian Hukum Islam di Perguruan Tinggi Keagamaan Islam Indonesia”. Jurnal Hukum Islam. Volume 16. Nomor 1. (Juni 2018). 